\title{
Bank Lending Efficiency in the Real Sector of the Economy of Ukraine within the Period of 2011 to 2014 Years
}

\author{
Mohammad Ayaz Ahmad ${ }^{*}$, Grigorii P. Kots², Vyacheslav V. Lyashenko ${ }^{*}$ \\ ${ }^{1}$ Physics Department, Faculty of Science, University of Tabuk, Tabuk, Saudi Arabia \\ ${ }^{2}$ Department of Information Systems, Kharkov National University of Economics, Kharkov, Ukraine \\ ${ }^{3}$ Laboratory "Transfer of Information Technologies in the Risk Reduction Systems", Kharkov National University \\ of RadioElectronics, Kharkov, Ukraine \\ Email: *mayaz.alig@gmail.com, "Iyashenko.vyacheslav@mail.ru
}

Received 27 October 2015; accepted 5 December 2015; published 10 December 2015

Copyright (C) 2015 by authors and Scientific Research Publishing Inc.

This work is licensed under the Creative Commons Attribution International License (CC BY).

http://creativecommons.org/licenses/by/4.0/

\section{(c) (i) Open Access}

\begin{abstract}
According to the classical theory of banking development and traditional idea of practical matters of bank management, lending is one of the main directions in banking. It is connected with that realization of credit transactions should be considered as a defining component of bank management. According to this defining component each separate bank will organize loan of resources and their subsequent arrangement on proper conditions and on proper risk. Hence, taking into account the retrospective review, the work analyzes the fluctuations of rating values of the bank lending efficiency in the real sector of the economy. The analysis is carried out on the example of the banks of Ukraine within the period of 2011 to 2014 years. For the purpose of examining the values of bank lending efficiency in the real sector of Ukraine's economy, the article considers the efficiency stochastic boundary model. There were analyzed in detail the forms of distribution by particular efficiency value levels of bank lending in the real sector of Ukraine's economy, which were obtained for 16 different time dates from the interval analyzed. There was made the conclusion about necessity of balanced use of real resources of banks for growth of crediting efficiency.
\end{abstract}

\section{Keywords}

Technical Efficiency, Bank Lending, Real Sector of Economy, Stochastic Efficiency Boundary, Loans, Deposits

\footnotetext{
${ }^{*}$ Corresponding author.
} 


\section{Introduction}

One of the conditions for stable and dynamic development of the real sector of the economy is the availability of financial resources from the different sources of their attraction. The importance of fulfillment of such condition is determined by the necessity of manufacture modernization and also by the opportunity for full-scale realization of innovative and investment projects acceptable for this kind of manufacture.

As the examples of such studies there can be noticed the works of Mario Quagliariello [1], Howard Pack and Larry E. Westphal [2], Chang-Tai Hsieh [3], Raymond Fisman and Inessa Love (2003) [4], which besides the observation of priority directions of lending of the real sector of the economy, there are also examined the questions of interrelations between lending terms in accordance with the state of development of the subjects of the real sector of the economy in particular and in the macroeconomic situation as a whole.

By analyzing the questions of financial resources attraction for the needs of different subjects of management in the real sector of economy, it is important to take into account the fact that among the main sources of such an attraction can be: banking system resources, stock exchange resources and also assets of potential investors that can be in their turn, as a rule, placed either in the stock market or in the banking system. So, in the system of modern economic interrelations the main sources of lending for different subjects of management in the real sector of the economy are resources of the banking sector of the economy and resources of the stock market. The key role of banking sector of the economy will consist in forming and maintenance of necessary conditions for free redistribution of financial resources among various subjects of managing for the purpose of their sufficing (subjects of managing) in need of such resources. Thus such necessity consists in security of steady and stable functioning of all subjects of the managing which is taking part in such redistribution of financial resources and their further forward development.

At the same time, using the materials of studies, presented in works of Graham Smith [5], Andreas Stephan, Oleksandr Talavera and Andriy Tsapin [6], in which there were analyzed and compared the opportunities for financial resources attraction for the needs of the real sector of Ukraine's economy, one can say that for Ukraine the resources of the banking sector but not the resources of the stock market, under existing economic conditions, are more stable and secure sources for attracting such funds. So, to uncover the chosen direction of the research we will observe, first of all, bank-lending efficiency of the real sector of Ukraine's economy, grounding on the dynamics of loans, given to legal persons - bank customers.

The topicality of observing the chosen direction of the research is also determined by the fact that bank lending is carried out not only at the particular bank's own risk, but also by the influence of different factors, in the surrounding of which both the bank and the potential borrower of bank resources are functioning, which leads to necessity of observing different credit questions as some valuations of such a process. Especially study of such questions is sharpened in the periods of unstable economic development, manifestation of economic and financial crises influence consequences, reformation of the existing system of economic interaction between different subjects of market interaction.

At the same time it is important to emphasize that at this time period Ukraine tends to go through instability of economic development, which influences the processes of bank lending. So, for example, at the present time in the practice of bank lending in Ukraine there are critical sharp questions of direct stimulation of the real sector of the economy and maintaining of the demand on credit resources from the population for revitalizing the domestic market of consumption, which directly determines the mechanisms of maintenance for manufacturers. So, determining, discovering and generalizing of any possible valuables of bank lending are an important practical task not only from the sphere of banking activity, but economic development on the whole, which allows using such valuables and also studying credit efficiency of the real sector of the economy.

\section{Technical Efficiency as One of the Valuables of Bank Lending Efficiency}

Assessment of bank lending efficiency can be made by studying a set of banking activity indicators using different approaches for obtaining such valuables. Especially among the indicators, used for study of bank lending efficiency valuables, one can pick out (see for example works by A. Sinan Cebenoyan and Philip E. Strahan [7], Yener Altunbas, Leonardo Gambacorta and David Marques-Ibanez [8], John Goddard et al. [9]):

The value of the effective credit rate, which depicts the real relative income, obtained on the whole within a year;

The net resulted income, which generalizes absolute meanings of the result obtained from bank credit activity; 
The domestic norm of profitability, reflecting debit percentage rate, according to which loans are viable and many others.

At the same time it's worth mentioning, that the most wide spread approach to assessment of bank lending efficiency commonly used lately, are methods, operating with the concept technical efficiency-efficiency, which is according to Dennis J. Aigner, Knox C. A. Lovell and Peter Schmidt [10] research allows to determine the rating of the ability to get a maximal output (a certain result), using a variety of inputs, discovering a set of different factors of the ability to reach a certain result (maximal input). As the examples of using technical efficiency in the field of banking activity analysis we can mention the works of Ali Ataullah, Tony Cockerill and Hang Le [11], Iftekhar Hasan and Katherin Marton [12], Fotios Pasiouras [13], Bannour Boutheina and Labidi Moez [14] and many others. The expediency of using technical efficiency for the analysis of economic processes of banks functioning is based on the idea that in this case the comparative aspects of particular banks activity are taken into account, and also it's possible to obtain statistic ratings of significance and reliability of the results of the analysis made.

For the purpose of uncovering technical efficiency in the field of banking activity analysis one constructs the so called efficiency border, which is typical for the methodology of stochastic boundaries analysis. The essence of such a methodology, according to studies of Aigner, Lovell and Schmidt [10], George Edward Battese and Tim J. Coelli [15] lies in:

Constructing the efficiency boundaries of the process or the phenomenon under research using the methods of statistic analysis in the form of some regressive dependence between the variables, chosen for such an analysis;

Positioning the process, phenomenon or object under investigation relative to the efficiency boundary obtained;

Evaluating the efficiency rating of the process, phenomenon or object under investigation using the methods of statistic analysis in the form of a certain regressive dependence between the variables chosen for such an analysis;

Positioning of the process, phenomenon or object under investigation with regard to the efficiency boundary obtained;

Evaluating the efficiency rating of the subject matter under study in the form of a function, characterizing the attainability of the efficiency boundary constructed, which, according to research of James Jondrow et al. [16] is presented in such a way:

$$
E f_{i}=e^{-M\left(u_{i} \mid \hat{\varepsilon}_{i}\right)}
$$

in which $E f_{i}$-technical efficiency (further also iust efficiencv) of the nrocess. nhenomenon or obiect under research $(i, \quad i=\overline{1, l}, l-$ a general number of the processes, phenomena or objects under research. In this case it is a number of banks under research, which realize lending of the business entity of the real sector of the Ukraine's economy.

$M\left(u_{i} \mid \widehat{\varepsilon}_{i}\right)$-a conditional mathematic expectation of a magnitude $u_{i}$ where estimated values $\widehat{\varepsilon}_{i}$ which are the complex constituent occasional members of the model for obtaining the efficiency boundaries of the process, object or phenomenon under research using the methods of a statistic analysis:

$$
\begin{aligned}
& y=f(x, C)+\varepsilon \\
& \varepsilon=v-u
\end{aligned}
$$

where $y$ is a vector of the results under research, $x$ is a vector of resources, used for obtaining results under research, $f$ is a function of the efficiency boundary under research. $C$ is a vector of function $\mathrm{f}$ parameters, $\varepsilon$ is a complex constituent random member of the model, which on the whole reflects inaccuracy of the model, $v$ is a vector of random fluctuations of the model, $u$ is a vector, characterizes technical inefficiency of the activity of the process, phenomenon or an object under research. On the assumption of the requirement of positive values of all constituent vectors $v$ and $u$; it is supposed, that these random components of the formalization of the efficiency boundary model can have in particular, a form of half-normal distribution $v \approx N\left(0, \sigma_{v}^{2}\right)$ and $u \approx N_{+}\left(0, \sigma_{u}^{2}\right)$, but their values $\sigma_{v}^{2}$ and $\sigma_{u}^{2}$. At the same time, taking into account an unusual structure of the inaccuracies of the efficiency boundary model, which has an asymmetric distribution and consists of two constituents, the remainders of the regression are principally assessed by the method of maximal plausibility.

As the analysis literature sources shows [12]-[14], most studies of efficiency in the field of banking activity 
are based on usage of industrial approach, operational approach or an intermediary approach, which is based on the expenditure approach. Nevertheless, a bank is first of all a financial intermediary between the potential owners of spare money resources and different subjects of market relations who need such resources. At that the important question is the study of the lending efficiency of the real sector of economy as the main direction of this research using the intermediary approach to construction of the efficiency boundary model on the basis of asset approach. This finally determines the main goal of this research.

\section{Used Model of Stochastic Boundary of Efficiency of Crediting}

So, to carry out the further analysis, first of all, it's necessary to study the model of efficiency stochastic boundary of functioning banks under study. To build a model of such efficiency boundary we will proceed from the reasonability of intermediary approach usage for description of bank activity on the basis of study of the asset approach. Also to build an appropriate model we will base on the results of prior studies of other authors, where the similar model of banking activity analysis was used. In particular as a similar model of stochastic boundary of bank lending efficiency in the real sector of the economy, the model used in the work of Oleg Vasyurenko, Vyacheslav Lyashenko and Valeriia Podchesova [17] or in the work of Vyacheslav Lyashenko [18] will be studied. These works analyses the efficiency of long-term bank lending depending on the volumes of the funds attracted in the form of deposits of physical and legal persons - bank customers, other banks' resources attracted at the interbank market and values of administrative and other operational expenses, depicting the real bank resources, which take part in the process of transformation of borrowing costs into granted loans.

Then the similar model of the efficiency stochastic boundary for assessment of lending efficiency in the real sector of the economy can be generalized as following:

$$
\ln \left(K R F_{i}\right)=C_{0}+C_{1} \cdot \ln \left(D I B_{i}\right)+C_{2} \cdot \ln \left(D P R_{i}\right)+C_{3} \cdot \ln \left(A O V_{i}\right)+v_{i}-u_{i}
$$

where $K R F_{i}$-lending capacity of business entities in the real sector of the economy in the context of each $i$ from the group of banks under study on the certain date of time, bln. hrn.;

$D I B_{i}$ - funds of other banks, that are attracted by means of interbank lending market in the context of each $i$ from the group of banks under study on the certain date of time, bln. hrn.;

$D P R_{i}$ — a volume of the funds attracted in the form of deposits from natural and legal persons-bank customers in the context of each $i$ from the group of banks under study on the certain date of time, bln. hrn.;

$A O V_{i}$ - a volume of administrative and other costs in the context of each $i$ from the group of Ukraine's banks under study on the certain date of time, bln. hrn.;

$C_{0}, C_{1}, C_{2}, C_{3}$-model factors.

On the whole the chosen variables of the presented above model corresponds totally the variables of the model of the banking activity description in accordance with the intermediary approach, based on the asset approach.

\section{Data for the Analysis}

For further realization of the model of the efficiency stochastic boundary for the purpose of obtaining the corresponding ratings of bank lending efficiency in the real sector of the economy in Ukraine there were studied the indicators of different Ukraine's banks activity that were taken from the official site of the National Bank of Ukraine-bank.gov.ua. This research covers the period from 2011 to 2014 taking into account their quarterly distribution. In other words, we study a quarterly bank lending efficiency in the real sector of Ukraine's economy within 2011-2014 years. Such a selection of data allows to analyze the dynamics of changes (in some aspect so called retrospective) of bank lending efficiency based on 16 separate time periods that were chosen for the research. At that, in every time period a different number of banks are used (see in the Table 1). A particular number of banks for each of certain time periods under study are stipulated by the need of correcting of the initial selection of banks where banks with zero values of the investigated parameters in the model of efficiency stochastic boundary were excluded.

The general dynamics of bank lending in the real sector of the economy of all Ukraine's banks in the investigated periods of time presented in the Figure 1 (Source: National Bank of Ukraine). As it can be seen from Figure 1, the general dynamics of bank lending in the real sector of Ukraine's economy, in spite of some time intervals with the descending tendency, can be considered positive.

The general dynamics of funds of other banks in the investigated periods of time presented in the Figure 2 
M. A. Ahmad et al.

Table 1. Parameters and statistic values of calculations results for the presented model of the efficiency stochastic boundary.

\begin{tabular}{|c|c|c|c|c|c|c|c|c|c|c|c|c|c|c|c|c|}
\hline \multirow{2}{*}{ Parameters } & \multicolumn{4}{|c|}{2011} & \multicolumn{4}{|c|}{2012} & \multicolumn{4}{|c|}{2013} & \multicolumn{4}{|c|}{2014} \\
\hline & 1 & 2 & 3 & 4 & 1 & 2 & 3 & 4 & 1 & 2 & 3 & 4 & 1 & 2 & 3 & 4 \\
\hline coeff. & 1.853 & 2.416 & 2.453 & 2.421 & 3.072 & 3.886 & 3.711 & 3.257 & 2.923 & 2.331 & 2.667 & 2.348 & 4.351 & 3.166 & 2.712 & 2.462 \\
\hline$C_{0}$ st.-error & 0.491 & 0.619 & 0.536 & 0.538 & 0.579 & 0.647 & 0.579 & 0.595 & 0.555 & 0.505 & 0.545 & 0.482 & 0.093 & 0.477 & 0.506 & 1.051 \\
\hline t-ratio & 3.769 & 3.899 & 4.577 & 4.504 & 5.308 & 6.005 & 6.399 & 5.472 & 5.272 & 4.617 & 4.899 & 4.874 & 6.822 & 6.643 & 5.361 & 2.341 \\
\hline coeff. & 0.269 & 0.212 & 0.253 & 0.097 & 0.089 & 0.085 & 0.134 & 0.151 & 0.102 & 0.033 & 0.026 & 0.099 & 0.157 & 0.091 & 0.067 & 0.059 \\
\hline$C_{1}$ st.-error & 0.035 & 0.043 & 0.043 & 0.042 & 0.038 & 0.049 & 0.036 & 0.039 & 0.037 & 0.033 & 0.038 & 0.029 & 0.024 & 0.025 & 0.023 & 0.051 \\
\hline t-ratio & 7.651 & 4.984 & 5.878 & 2.335 & 2.345 & 1.696 & 3.732 & 3.815 & 2.766 & 0.997 & 0.679 & 3.327 & 6.529 & 3.567 & 2.901 & 1.161 \\
\hline coeff. & 0.699 & 0.647 & 0.645 & 0.657 & 0.724 & 0.567 & 0.491 & 0.496 & 0.618 & 0.808 & 0.843 & 0.848 & 0.492 & 0.518 & 0.603 & 0.537 \\
\hline$C_{2}$ st.-error & 0.071 & 0.091 & 0.080 & 0.079 & 0.082 & 0.095 & 0.071 & 0.058 & 0.081 & 0.082 & 0.091 & 0.075 & 0.037 & 0.083 & 0.092 & 0.115 \\
\hline t-ratio & 9.841 & 7.144 & 8.042 & 8.271 & 8.822 & 5.965 & 6.943 & 8.485 & 7.667 & 9.886 & 9.252 & 11.281 & 13.428 & 6.242 & 6.562 & 666 \\
\hline coeff. & -0.039 & 0.051 & 0.002 & 0.162 & 0.033 & 0.180 & 0.228 & 0.238 & 0.180 & 0.052 & -0.005 & -0.075 & 0.191 & 0.297 & 0.240 & 0.349 \\
\hline$C_{3}$ st.-error & 0.085 & 0.111 & 0.002 & 0.089 & 0.089 & 0.108 & 0.083 & 0.073 & 0.096 & 0.094 & 0.106 & 0.083 & 0.095 & 0.097 & 0.097 & 0.154 \\
\hline t-ratio & -0.464 & 0.458 & 0.021 & 1.798 & 0.369 & 1.659 & 2.758 & 3.273 & 1.879 & 0.553 & -0.045 & $5-0$ & 2.021 & 3.073 & 2.487 & 2.261 \\
\hline coeff. & 1.232 & 1.395 & 1.272 & 1.307 & 1.716 & 2.738 & 2.458 & 2.336 & 1.384 & 1.299 & 1.955 & 1.147 & 3.636 & 1.403 & 1.062 & 1.526 \\
\hline$\sigma^{2}$ st.-error & 0.194 & 0.244 & 0.205 & 0.211 & 0.259 & 0.377 & 0.351 & 0.329 & 0.215 & 0.192 & 0.282 & 0.185 & 0.039 & 0.226 & 0.222 & 0.941 \\
\hline t-ratio & 6.355 & 5.712 & 6.195 & 6.203 & 6.619 & 7.257 & 6.999 & 7.090 & 6.449 & 6.774 & 6.935 & 6.217 & 9.426 & 6.208 & 4.784 & 1.622 \\
\hline coeff. & 0.902 & 0.794 & 0.841 & 0.846 & 0.907 & 0.912 & 0.937 & 0.944 & 0.843 & 0.885 & 0.923 & 0.819 & 0.907 & 0.903 & 0.857 & 0.887 \\
\hline$\gamma$ st.-error & 0.043 & 0.076 & 0.056 & 0.055 & 0.038 & 0.029 & 0.027 & 0.024 & 0.050 & 0.192 & 0.026 & 0.058 & 0.001 & 0.042 & 0.086 & 0.398 \\
\hline t-ratio & 20.961 & 10.388 & 14.912 & 15.413 & 23.758 & 31.372 & 34.442 & 38.959 & 16.773 & 23.173 & 35.076 & 13.956 & 37.400 & 21.430 & 10.008 & 2.228 \\
\hline $\log L R$ & -161.4 & -186.9 & -173.1 & -17 & -186.1 & -221.9 & - & - & -1 & - & & & & - & & -1 \\
\hline $\begin{array}{l}\text { A number of } \\
\text { banks under } \\
\text { study }\end{array}$ & 154 & 154 & 154 & 151 & 155 & 156 & 154 & 148 & 152 & 156 & 154 & 154 & 154 & 141 & 137 & 127 \\
\hline
\end{tabular}

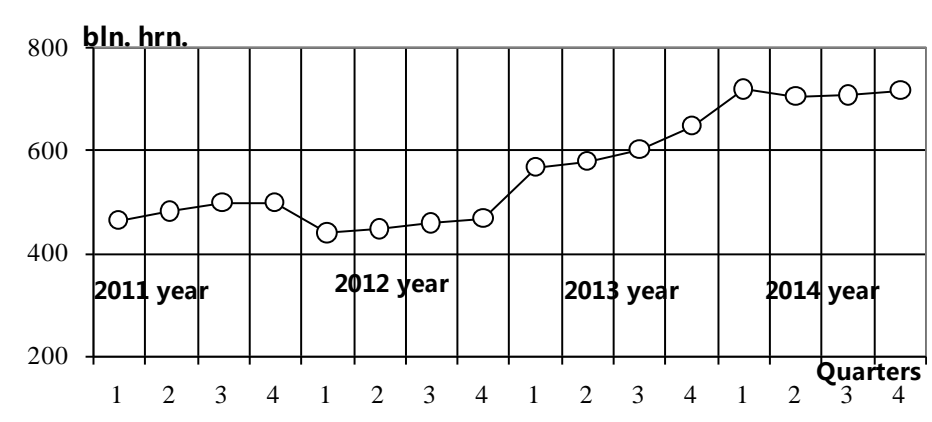

Figure 1. General dynamics of the volumes of bank lending in the real sector of economy of all Ukraine's banks within 2011-2014 years.

(Source: National Bank of Ukraine).

The general dynamics of volume of the funds attracted in the form of deposits from natural and legal persons in the investigated periods of time presented in the Figure 3 (Source: National Bank of Ukraine). As it can be seen from Figure 3, the general dynamics of volume of the funds attracted in the form of deposits from natural and legal persons can be considered positive. 


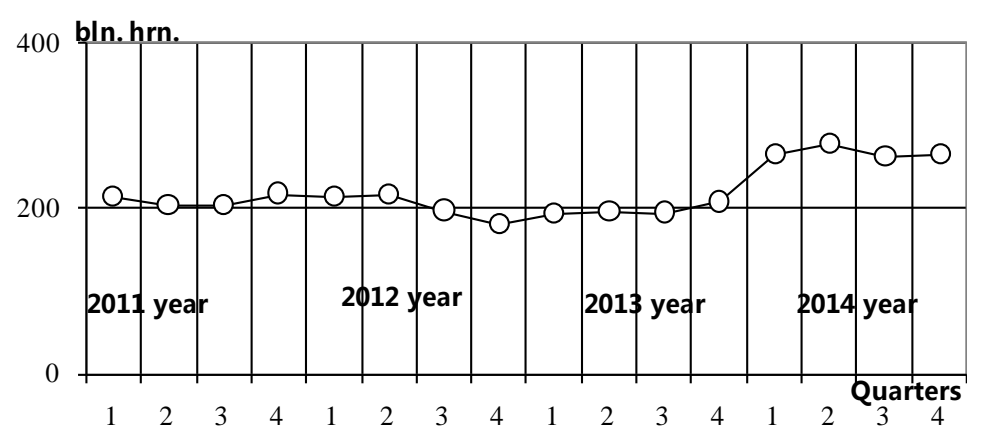

Figure 2. General dynamics funds of other banks of all Ukraine’s Banks within 2011-2014 years.

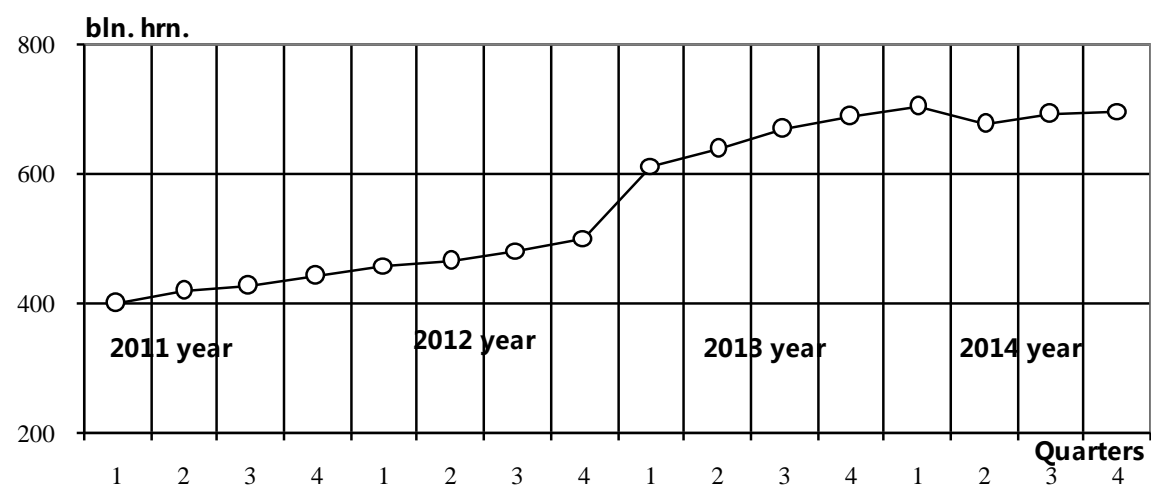

Figure 3. General dynamics of volume of the funds attracted in the form of deposits from natural and legal persons of all Ukraine's Banks within 2011-2014 years.

The general dynamics of volume of administrative and other costs in the investigated periods of time presented in the Figure 4 (Source: National Bank of Ukraine).

\section{The Statistic Values of the Parameters of the Investigated Efficiency Boundary Model}

To determine the parameters of the efficiency boundary models in each selected periods of time and to calculate the values of bank lending efficiency in the real sector of the economy CEPA's (Centre for Efficiency and Productivity Analysis) software was used-the programme FRONTIER 4., which is free and has an open access.

The results of calculations of programme FRONTIER 4.1 for determining parameters of the investigated efficiency stochastic boundary model on the basis of selected data are presented in Table 1.

In particular, Table 1 shows:

$C_{0}, C_{1}, C_{2}, C_{3}$ coefficients of the investigated model and their statistic values-a standard error and t-ration at the relevancy level 0.05 for certain periods of time;

a value of full dispersion inaccuracy $\sigma^{2}=\sigma_{v}^{2}+\sigma_{u}^{2}$, which determines the key parameters of occasional components distribution in the investigated model and their statistic values-standard error and t-ratio at the relevancy level 0.05 for certain periods of time;

a value of inefficient constituent share $\gamma=\sigma_{u}^{2} / \sigma^{2}$ in full dispersion of inaccuracy and their statistic values —a standard error and t-ratio at the relevancy level 0.05 for certain periods of time;

a ratio of a logarithm function of maximal likelihood (LR) for certain periods of time;

a number of banks under study in certain periods of time.

First of all, the analysis of data in Table 1 indicates the substantial share of inefficient constituent in full dispersion of the error of the investigated model of bank lending efficiency boundary in the real sector of the economy. It can be also an illustration of the presence of a substantial share of inefficiency in the processes of transformation of borrowed funds into lending resources in respect to Ukraine's banks functioning. 


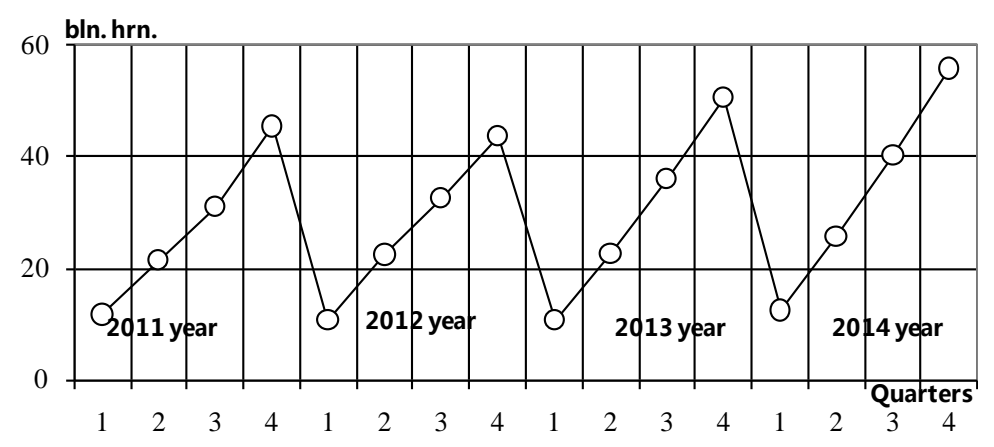

Figure 4. General dynamics of volume of administrative and other costs of all Ukraine’s Banks within 2011-2014 years.

At the same time, data in Table 1 on the whole suggest the significance of the obtained results and investigated model of efficiency stochastic boundary. The least significant are values of $C_{3}$ coefficients with such a parameter of the investigated model as $A O V_{i}$, that reflects the dynamics of changes of administrative and other operational costs volumes of the investigated banks. At that, an inessential statistic dependence of such coefficients at the rate of significance 0.05 is observed only in certain periods of time. From the economic point of view the explanation of such a fact can be a various quarterly dynamics of the speed of alteration of granted loans volumes and administrative and other operational costs of the investigated banks (Figure 1 and Figure 4).

At the same time it should be noticed, that an inessential statistic dependence of values $C_{3}$ coefficients is observed in the periods of considerable excess of rate of growth of administrative and other operational costs in comparison with rates of growth of lending volumes in the real sector of the economy. In other words, the costs of the real resources of the banks didn't correspond to the rate of lending volumes alteration. By the way, in these periods of time you can observe the decrease of values $C_{3}$ of coefficients, which is an objective evidence of decrease of the influence of administrative and other operational costs on the dynamics of bank lending volumes in the real sector of the economy. So, it can be concluded, that a part of a share of an inefficient constituent in the processes of transformation of borrowed funds into lending resources in respect to Ukraine's banks functioning is determined by the irrelevant tendencies in changes of volumes of administrative and other costs of the banks to the real tendencies of changes of lending volumes in the real sector of the economy.

At the same time, reasoning from the data of Table 1, values of $C_{2}$ coefficients, it should be noticed a considerable influence of the volumes of the attracted funds in the form of physical and legal persons' deposits on the dynamics of bank lending volumes in the real sector of the economy, which is explicable fact from the objective point of view. At that, the dynamics of values of $C_{1}$ coefficients can be the evidence of a considerable variability of the influence of other banks' resources, attracted by the means of the interbanking lending market, on the dynamics of bank lending volumes of the real sector of the economy. Nevertheless, this fact has quite a logical explanation, which is based on the fact, that resources of other banks are mainly used for a maintaining of a proper liquidity rate with the purpose of meeting the requirements of the bank in necessary resources.

\section{Values of Lending Efficiency}

Another result of the programme product FRONTIER 4.1 is a direct calculation of efficiency ratings-in this case the ratings of bank lending efficiency in the real sector of Ukraine's economy. Like a calculation of parameters of the model of efficiency stochastic boundary, the calculation of the ratings of bank lending efficiency in the real sector of Ukraine's economy is performed for particular quarters from the investigated period from 2011 to 2014 years. The generalized results of such calculations are presented in Figure 5 in the form of separated, for each of investigated quarters within 2011-2014 years, bar graph of bank lending efficiency in the real sector of the economy. Corresponding ratings of bank lending efficiency in the real sector of the economy are given in fractions of unity and presented in Figure 5 by ten levels: first level 0.1 - corresponds a set of different banks, which have values from 0 to 0.1 inclusive, the second level 0.2 -from 0.1 to 0.2 inclusive and so forth. At the same time along the $\mathrm{Y}$-axis there was laid off the frequency-a number of banks which are typical for each level of investigated ratings in the context of separated quarters.

Substantial changes in the distribution levels of investigated bank lending efficiency ratings took place in 


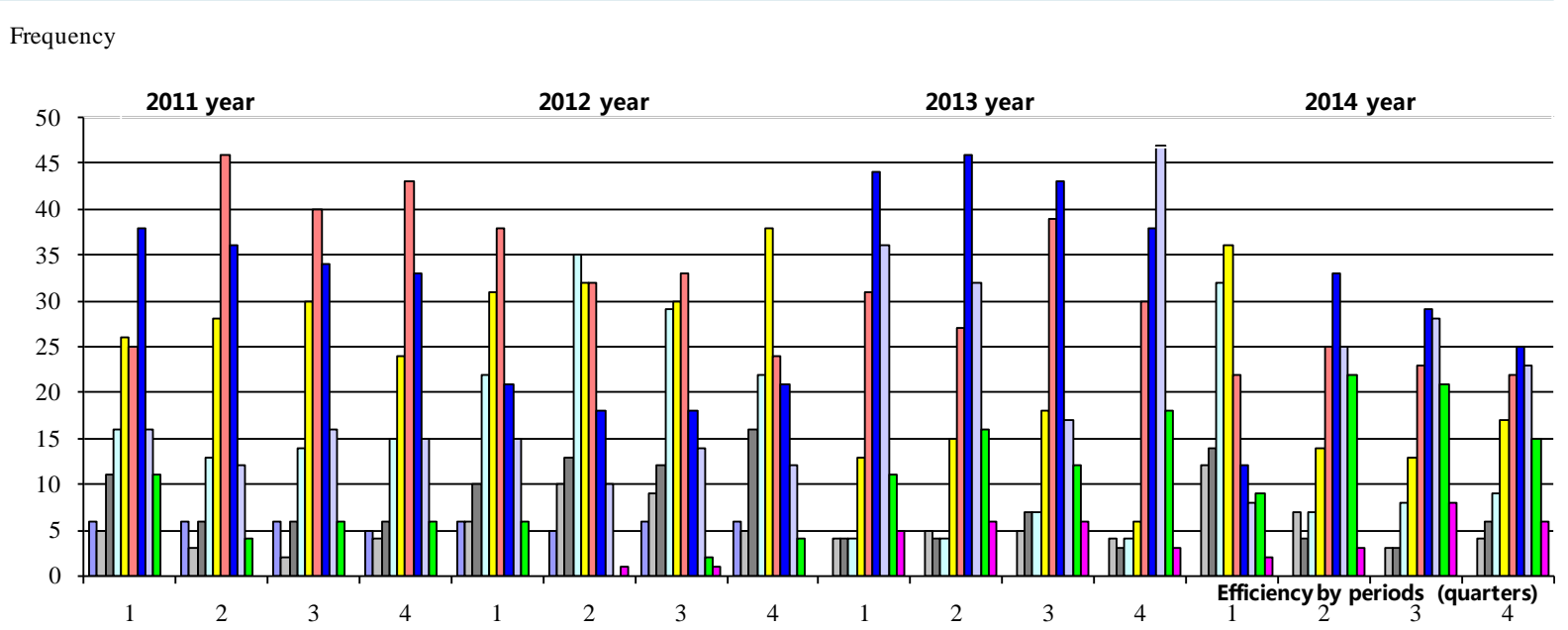

efficiency levels:

$\square 0.1 \square 0.2 \square 0.3 \square 0.4 \square 0.5 \square 0.6 \square 0.7 \quad \square 0.8 \quad \square 0.9 \square 1$

Figure 5. A battery of bar graphs of bank lending efficiency in the real sector of Ukraine's economy in the context of particular quarters within the period.

2011. Here, as it can be seen from the data of Figure 5, starting with the second quarter of 2011, the rating at the level 0.6 begins to prevail. At this such a tendency doesn't get better, but even get worse.

So, according to the results:

the first quarter of 2012 a number of banks with the rating of bank lending efficiency in the real sector of the economy decreases by 0.6 in comparison with the data of 2011,

the second quarter of 2012 - the prevailing is the efficiency rating at the level 0.4,

the third quarter of 2012 the efficiency rating at the level 0.6 prevails slightly in comparison with the efficiency ratings at levels 0.4 and 0.5 ,

the fourth quarter - the prevailing is the efficiency rating at the level 0.5 .

Substantial changes in the distribution levels of investigated bank lending efficiency ratings took place and in 2013 and in 2014 (Figure 5).

The dynamics of the average rating of the bank lending efficiency of the real sector of Ukraine's economy presented in the Figure 6.

First of all, on the assumption of the data of Figure 6, it should be noticed a negative tendency in changes of mean values of the ratings of bank lending efficiency in the real sector of Ukraine's economy within the whole investigated period. As a whole among the reasons of observable decrease in efficiency of bank lending in Ukraine it is necessary to note both insufficient use of resources of other banks which are involved by means of the market of interbank lending for the purpose of expansion of bank lending of the real sector in Ukraine, and considerable administrative and other operational expenses which are unbalanced with dynamics of volumes of granted credits.

If we compare the dynamics of changes of average rating values of bank lending efficiency in the real sector of economy with the dynamics of volumes of bank lending of the real sector of economy for all the Ukraine's banks, it should be noticed the presence of a particular lag in such dependences. Manifesting such lag dependence of the investigated values is the inertness of reaction of bank lending processes, which shows itself in corresponding lending volumes, on a change of levels of such lending efficiency. The explanation of such a fact is a general inertness of bank system reaction, which is a complex polyhierarchic, but dynamic mechanism of modern market relations.

\section{Conclusions}

Thus, the considered model of stochastic boundary of efficiency of crediting can be used for derivation of aver- 


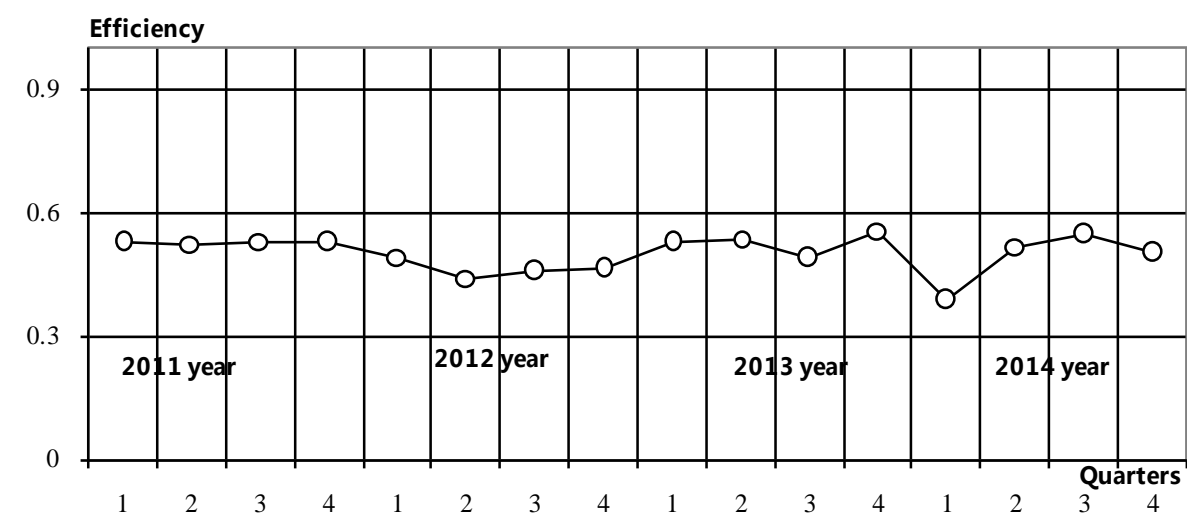

Figure 6. The dynamics of the average rating of the bank lending efficiency of the real sector of Ukraine's economy within 2011-2014 years.

age estimations of efficiency of bank crediting of real sector of economy in the context of separate banking groups. Especially, use of the offered model of stochastic boundary of efficiency of crediting allows drawing a conclusion about decrease of estimation of efficiency of bank crediting of real sector of economy in Ukraine for investigated period of time. In the end it doesn't contribute to substantial growth of the dynamics of rating values of bank lending efficiency in the real sector of Ukraine's economy.

One of the factors that influence on the decrease of the efficiency of the process of transformation of attracted resources into lending resources, and consequently bank lending efficiency, is inconsistent with high rates of changes of volumes of administrative and other operational costs of the investigated banks as compared with the dynamics of bank lending volumes in the real sector of the economy.

Also no less important problem is the question of increase of efficiency of processes of bank crediting of real sector of economy which is in a plane of adequacy and equation of use of real resources of banks.

So, the key issue of increase of efficiency of processes of bank lending efficiency in the real sector of Ukraine's economy is a matter of adequate usage of the real resources of banks.

\section{References}

[1] Quagliariello, M. (2009) Macroeconomic Uncertainty and Banks’ Lending Decisions: The Case of Italy. Applied Economics, 41, 323-336. http://dx.doi.org/10.1080/00036840601007286

[2] Pack, H. and Westphal, L.E. (1986) Industrial Strategy and Technological Change: Theory versus Reality. Journal of Development Economics, 22, 87-128. http://dx.doi.org/10.1016/0304-3878(86)90053-2

[3] Hsieh, C.T. (2002) What Explains the Industrial Revolution in East Asia? Evidence from the Factor Markets. The American Economic Review, 92, 502-526. http://dx.doi.org/10.1257/00028280260136372

[4] Fisman, R. and Love, I. (2003) Trade Credit, Financial Intermediary Development, and Industry Growth. The Journal of Finance, 58, 353-374. http://dx.doi.org/10.1111/1540-6261.00527

[5] Smith, G. (2009) Martingales in European Emerging Stock Markets: Size, Liquidity and Market Quality. The European Journal of Finance, 15, 249-262. http://dx.doi.org/10.1080/13518470802423262

[6] Stephan, A., Talavera, O. and Tsapin, A. (2011) Corporate Debt Maturity Choice in Emerging Financial Markets. The Quarterly Review of Economics and Finance, 51, 141-151. http://dx.doi.org/10.1016/j.qref.2010.12.003

[7] Cebenoyan, A.S. and Strahan, P.E. (2004) Risk Management, Capital Structure and Lending at Banks. Journal of Banking \& Finance, 28, 19-43. http://dx.doi.org/10.1016/S0378-4266(02)00391-6

[8] Altunbas, Y., Gambacorta, L. and Marques-Ibanez, D. (2009) Securitisation and the Bank Lending Channel. European Economic Review, 53, 996-1009. http://dx.doi.org/10.1016/j.euroecorev.2009.03.004

[9] Goddard, J., Molyneux, P., Wilson, J.O.S. and Tavakoli, M. (2007) European Banking: An Overview. Journal of Banking \& Finance, 31, 1911-1935. http://dx.doi.org/10.1016/j.jbankfin.2007.01.002

[10] Aigner, D.J., Lovell, K.C.A. and Schmidt, P. (1977) Formulation and Estimation of Stochastic Frontier Production Function Models. Journal of Econometrics, 6, 21-37. http://dx.doi.org/10.1016/0304-4076(77)90052-5

[11] Ataullah, A., Cockerill, T. and Le, H. (2004) Financial Liberalization and Bank Efficiency: A Comparative Analysis of India and Pakistan. Applied Economics, 36, 1915-1924. http://dx.doi.org/10.1080/000368404200068638 
[12] Hasan, I. and Marton, K. (2003) Development and Efficiency of the Banking Sector in a Transitional Economy: Hungarian Experience. Journal of Banking \& Finance, 27, 2249-2271. http://dx.doi.org/10.1016/S0378-4266(02)00328-X

[13] Pasiouras, F. (2008) International Evidence on the Impact of Regulations and Supervision on Banks’ Technical Efficiency: An Application of Two-Stage Data Envelopment Analysis. Review of Quantitative Finance and Accounting, 30 , 187-223. http://dx.doi.org/10.1007/s11156-007-0046-7

[14] Boutheina, B. and Moez, L. (2013) Efficiency of the Tunisian Trade Banks: Study by the Stochastic Frontier Approach. Panoeconomicus, 60, 103-132. http://dx.doi.org/10.2298/PAN1301103B

[15] Battese, G.E. and Coelli, T.J. (1992) Frontier Production Functions, Technical Efficiency and Panel Data: With Application to Paddy Farmers in India. Journal of Productivity Analysis, 3, 153-169. http://dx.doi.org/10.1007/BF00158774

[16] Jondrow, J., Lovell, C.A.K., Materov, I.S. and Schmidt, P. (1982) On the Estimation of Technical Inefficiency in the Stochastic Frontier Production Function Model. Journal of Econometrics, 19, 233-238. http://dx.doi.org/10.1016/0304-4076(82)90004-5

[17] Vasyurenko, O., Lyashenko, V. and Podchesova, V. (2014) Efficiency of Lending to Natural Persons and Legal Entities by Banks of Ukraine: Methodology of Stochastic Frontier Analysis. Herald of the National Bank of Ukraine, 1, 5-11.

[18] Lyashenko, V. (2014) Efficiency of Bank Crediting of Real Sector of Economy in the Context of Separate Banking Groups: An Empirical Example from Ukraine. International Journal of Accounting and Economics Studies, 2, 74-79. http://dx.doi.org/10.14419/ijaes.v2i2.3064 